\title{
Effect of NPK and Neem Cake on Physical and Chemical Properties of Soil in Cluster Bean (Cyamopsis tetragonoloba L.) Cv. Pusa Navbahar
}

\author{
Bhanwar Lal Choudhary ${ }^{1}$, Jitendra Singh Bamboriya ${ }^{{ }^{*}}$, \\ Tarence Thomas ${ }^{1}$, Sarita $^{3}$ and Shankar Lal Bijarnia ${ }^{4}$
}

${ }^{1}$ Department of Soil Science, Sam Higginbottom University of Agriculture, Technology \& Sciences, Allahabad (U.P.), India

${ }^{2}$ Department of Soil Science and Agricultural Chemistry, Maharana Pratap University of Agriculture and Technology, Udaipur, Rajasthan, India

${ }^{3}$ Department of Agronomy, Agriculture University, Jodhpur, Rajasthan, India

${ }^{4}$ Department of Soil Science and Agricultural Chemistry, SKRAU Bikaner, Rajasthan, India

*Corresponding author

\section{A B S T R A C T}

\section{Ke y w o r ds \\ Cluster bean, NPK, Neem cake, \\ Physical, Chemical properties}

\section{Article Info}

Accepted:

15 March 2020 Available Online: 10 April 2020
A field experiment which was carried out at the Soil Science Research Farm, Sam Higginbottom University of Agriculture, Technology and Sciences-Deemed to be University, Allahabad during kharif season, 2015. The experiment was conducted in factorial randomized block design with three level of $\mathrm{N}: \mathrm{P}: \mathrm{K}$ [control $\left(\mathrm{L}_{0}\right)$, $\mathrm{N}_{10} \mathrm{P}_{20} \mathrm{~K}_{20}\left(\mathrm{~L}_{1}\right)$ and $\mathrm{N}_{20} \mathrm{P}_{40} \mathrm{~K}_{40}\left(\mathrm{~L}_{2}\right)$ ] and three levels of Neem cake [control $\left(\mathrm{N}_{0}\right)$, @ $2.5 \mathrm{q} \mathrm{ha}^{-1}\left(\mathrm{~N}_{1}\right)$ and @ $\left.5.0 \mathrm{q} \mathrm{ha}^{-1}\left(\mathrm{~N}_{2}\right)\right]$. The present investigation revealed that among fertility levels application of $\mathrm{N}_{20} \mathrm{P}_{40} \mathrm{~K}_{40}\left(\mathrm{~L}_{2}\right)$ recorded the lowest $\mathrm{pH}$ (6.93) and bulk density $\left(1.06 \mathrm{Mg} \mathrm{m}^{-3}\right)$ and highest in pore space, organic carbon, available nitrogen, available phosphorus and available potassium $(49.67 \%, 0.75 \%$, $322.39 \mathrm{~kg} \mathrm{ha}^{-1}, 31.88 \mathrm{~kg} \mathrm{ha}^{-1}$ and $201.64 \mathrm{~kg} \mathrm{ha}^{-1}$, respectively). Among different levels of neem cake, application of $5.0 \mathrm{q} \mathrm{ha}^{-1}\left(\mathrm{~N}_{2}\right)$ neem cake recorded the lowest $\mathrm{pH}$ (6.97) and bulk density (1.07 $\mathrm{Mg} \mathrm{m}^{-3}$ ) and highest in pore space, organic carbon, available nitrogen, available phosphorus and available potassium (49.01\%, $0.71 \%, 311.91 \mathrm{~kg} \mathrm{ha}^{-1}, 29.19 \mathrm{~kg} \mathrm{ha}^{-1}$ and $183.37 \mathrm{~kg} \mathrm{ha}^{-1}$, respectively).

\section{Introduction}

Cluster bean [Cyamopsis tetragonoloba (L.) Taub] popularly referred to as "Guar" is a crucial legume crop mainly grown in arid and semi-regions of Rajasthan under rainfed condition during kharif season. It is very hardy and drought tolerant crop. Its deep penetrating roots enable the plant to utilize available moisture more efficiently and thus offer better scope for rainfed cropping. The crop also tolerates moderate salinity and 
alkalinity conditions. In legume crops there is no other crop so hardy and drought tolerant as cluster bean (Kherawat et al., 2013). Due to high degree of drought and salinity tolerance, guar could be a valuable alternative crop for the exploitation of the semi-arid environment, where high temperature, poor erratic rainfall and elevated soil salt content restrict the cultivation of other crops. In India, it is grown in an area of 4.10 million hectares with a production of 1.85 million tonnes and productivity of $451 \mathrm{~kg} / \mathrm{ha}$ and is annually contributing to around $80 \%$ share to the world's total production (Agricultural Statistics at a Glance 2018).

Cluster bean being a legume crop which has the capacity to fix atmospheric nitrogen by its effective root nodules, the major part of nitrogen is met up through rhizobium impending in the root nodules hence; crop does not require supernumerary nitrogen for its initial growth and development phase. Fertilizer nitrogen, apart from increasing the content of nitrate in soil that leads to its leaching (Porter et al., 1996), results in changes in soil $\mathrm{pH}$ and many other soil properties (Brady and Weil , 2002). An application of phosphorus exerts an influences symbiotic nitrogen fixation, yield and quality of cluster pods. Phosphorus has a positive and significant sway on nodulation and crop yield and also increasing the activity of rhizobium. Phosphorus also meliorates the quality of cluster bean grain.

Neem cake acts as a nitrogen inhibitor and supplies the available nitrogen in the soil for a long time (Katyayan, 2012). The composition of neem cake is $5.2 \% \mathrm{~N}, 1.0 \% \mathrm{P}_{2} \mathrm{O}_{5}$ and $1.4 \%$ $\mathrm{K}_{2} \mathrm{O}$. Neem cake functions as dual performance of both fertilizer and pesticide, acts as a soil enriches, provides essential macro nutrients for all plant, pare down the growth of soil pest and bacteria, redound to the yield of plants for long period, eco- friendly and bio degradable and splendiferous soil conditioner. Application of neem soil conditioner in plantation crops that helps to increase its fertility (Lokanadhan et al., 2012). Neem cake also acts as a nematicide.

\section{Materials and Methods}

An experiment was conducted at Dept. of Soil Science Research Farm, of Sam Higginbottom University of Agriculture, Technology and Sciences (Deemed-to-beUniversity), Allahabad during kharif season of 2015 on alluvial soil, to evaluate the effect of NPK and neem cake on growth, yield attributing characters and yield of cluster bean. Geographically, the experimental site is situated on the south of Allahabad on the right side of the river Yamuna on the South of Rewa Road at a distance of about $6 \mathrm{~km}$ from Allahabad city. It is situated at $25^{0} 57^{\prime \prime} \mathrm{N}$ latitude, $81^{0} 59$ " E longitude and at the altitude of 98 meter above the sea level. The area of Allahabad district comes under subtropical belt in the South East of Uttar Pradesh, which experience extremely hot summer and fairly cold winter. The maximum temperature of the location reaches up to $46^{\circ} \mathrm{C}-48^{\circ} \mathrm{C}$ and seldom falls as low as $4^{0} \mathrm{C}-5^{0} \mathrm{C}$ in the winter. The relative humidity ranged between 20 to $94 \%$. The average rainfall in this area is around $1100 \mathrm{~mm}$ annually.

The soil of the experimental field was sandy laom in texture, poor in organic carbon $(0.47 \%)$, low in available nitrogen $(235.65 \mathrm{~kg}$ $\mathrm{ha}^{-1}$ ) and medium in phosphorus $(20.92 \mathrm{~kg}$ $\mathrm{ha}^{-1}$ ) and potassium (126.82 $\mathrm{kg} \mathrm{ha}^{-1}$ ) (Table 1). The experiment consisted of three levels of fertility [control $\left(\mathrm{L}_{0}\right), \mathrm{N}_{10} \mathrm{P}_{20} \mathrm{~K}_{20}\left(\mathrm{~L}_{1}\right)$ and $\left.\mathrm{N}_{20} \mathrm{P}_{40} \mathrm{~K}_{40}\left(\mathrm{~L}_{2}\right)\right]$ and three levels of neem cake [control $\left(\mathrm{N}_{0}\right)$, @ $2.5 \mathrm{q} \mathrm{ha}^{-1}\left(\mathrm{~N}_{1}\right)$ and @ $5.0 \mathrm{q}$ $\left.\mathrm{ha}^{-1}\left(\mathrm{~N}_{2}\right)\right]$. The total 9 treatment combinations were tested in factorial randomized block design with three replications. Cluster bean variety 'Pusa Navbahar' was sown at $30 \mathrm{~cm} \mathrm{x}$ 
$15 \mathrm{~cm}$ row and plant to plant spacing on 22th July 2015 with a seed rate of $20 \mathrm{~kg} \mathrm{ha}^{-1}$. Fertilizers were applied as per treatment through diammonium phosphate (DAP) containing $46 \% \quad \mathrm{P}_{2} \mathrm{O}_{5}$ and $18 \% \quad \mathrm{~N}$, urea containing $46 \% \mathrm{~N}$, MOP containing $60 \% \mathrm{~K}_{2} \mathrm{O}$ and Neem Cake at the time of sowing as per treatment.

\section{Results and Discussion}

\section{Effect of fertility levels}

Soil physical properties like bulk density $\left(1.06 \mathrm{Mg} \mathrm{m}^{-3}\right)$ and particle density $(2.31 \mathrm{Mg}$ $\mathrm{m}^{-3}$ ) were in the lowest order with the application of $\mathrm{N}_{20} \mathrm{P}_{40} \mathrm{~K}_{40}$ and $\mathrm{N}_{0} \mathrm{P}_{0} \mathrm{~K}_{0}$, respectively.

The maximum soil pore space was recorded $49.67 \%$ with the application of $\mathrm{N}_{10} \mathrm{P}_{20} \mathrm{~K}_{20}\left(\mathrm{~N}_{1}\right)$ and minimum soil pore space was recorded $46.64 \%$ with the application of $\mathrm{N}_{0} \mathrm{P}_{0} \mathrm{~K}_{0}\left(\mathrm{~N}_{0}\right)$. Soil chemical properties like $\mathrm{pH}$ (6.93) and EC $\left(0.19 \mathrm{dSm}^{-1}\right)$ were in the lowest order with the application of $\mathrm{N}_{20} \mathrm{P}_{40} \mathrm{~K}_{40}$ and control, respectively as compared to other fertilizer treatments.

Increasing dose of NPK slightly decrease $\mathrm{pH}$ of the post-harvest soil. The decrease in $\mathrm{pH}$ might be due to higher growth of crops as respiration is more. Respiration evolves carbon dioxide and reacts with water to form carbonic acid in soil.

Application of fertilizers @ $\mathrm{N}_{20} \mathrm{P}_{40} \mathrm{~K}_{40}$ to cluster bean recorded significantly higher organic carbon $(0.75 \%)$, available nitrogen (322.39 kg ha ${ }^{-1}$ ), available phosphorus (31.88 $\left.\mathrm{kg} \mathrm{ha}^{-1}\right)$ and available potassium $(201.64 \mathrm{~kg}$ $\left.\mathrm{ha}^{-1}\right)$ as compared to control $(0.58 \%, 287.70$ $\mathrm{kg} \mathrm{ha}^{-1}, 23.19 \mathrm{~kg} \mathrm{ha}^{-1}$ and $143.45 \mathrm{~kg} \mathrm{ha}^{-1}$, respectively) (Table 2). Similar findings were recorded by Kumar et al., (2008) and Takase et al., (2011).

\section{Effect of neem cake}

Soil physical properties like bulk density $\left(1.08 \mathrm{Mg} \mathrm{m}^{-3}\right)$ and particle density $(2.42 \mathrm{Mg}$ $\mathrm{m}^{-3}$ ) were in the lowest order with the application of neem cake @ $5.0 \mathrm{q} \mathrm{ha}^{-1}\left(\mathrm{~N}_{2}\right)$ and control $\left(\mathrm{N}_{0}\right)$, respectively. The maximum soil pore space was recorded $49.01 \%$ with the application of neem cake @ $5.0 \mathrm{q} \mathrm{ha}^{-1}\left(\mathrm{~N}_{2}\right)$ and minimum soil pore space was recorded $47.99 \%$ with the application of neem cake @ $2.5 \mathrm{q} \mathrm{ha}^{-1}\left(\mathrm{~N}_{1}\right)$.

Soil chemical properties like $\mathrm{pH}$ (6.97) and EC $\left(0.21 \mathrm{dSm}^{-1}\right)$ were in the lowest order with the application of neem cake @ $5 \mathrm{~kg} \mathrm{ha}^{-1}$ and control, respectively as compared to other treatments. Application of neem cake @ 5.0 q $\mathrm{ha}^{-1}$ to cluster bean recorded significantly higher organic carbon $(0.71 \%)$, available phosphorus $\left(29.18 \mathrm{~kg} \mathrm{~h}^{-1}\right)$ and available potassium $\left(183.37 \mathrm{~kg} \mathrm{ha}^{-1}\right)$ as compared to control $\left(0.64 \%, 26.34 \mathrm{~kg} \mathrm{ha}^{-1}\right.$ and $165.55 \mathrm{~kg}$ $\mathrm{ha}^{-1}$, respectively) while available nitrogen higher under the treatment $\mathrm{N}_{2}$ (@5.0 q ha ${ }^{-1}$ ) $\left(311.97 \mathrm{~kg} \mathrm{ha}^{-1}\right)$ which is at par with the treatment $\mathrm{N}_{1}\left(@ 2.5 \mathrm{q} \mathrm{ha}^{-1}\right)\left(308.42 \mathrm{~kg} \mathrm{ha}^{-1}\right)$ (Table 3).

The interaction effect of NPK and neem cake on phosphorus indicated significantly superior performance of $\mathrm{N}_{20} \mathrm{P}_{40} \mathrm{~K}_{40}$ and neem cake @ $5.0 \mathrm{q} \mathrm{ha}^{-1}\left(33.68 \mathrm{~kg} \mathrm{ha}^{-1}\right)$ as compared to remaining treatments combinations and highest organic carbon recorded under the treatment combination of $\mathrm{T}_{8}-\mathrm{N}_{20} \mathrm{P}_{40} \mathrm{~K}_{40}$ and neem cake@ @ $5.0 \mathrm{q} \mathrm{ha}^{-1}(0.78 \%)$ which is at par with the treatment combination of $\mathrm{T}_{7}-$ $\mathrm{N}_{20} \mathrm{P}_{40} \mathrm{~K}_{40}$ and neem cake @ $2.5 \mathrm{q} \mathrm{ha}^{-1}$ $(0.75 \%)$ while the nitrogen and potassium highest recorded under the treatment $\mathrm{T}_{8}-$ $\mathrm{N}_{20} \mathrm{P}_{40} \mathrm{~K}_{40}$ and neem cake @ $5.0 \mathrm{q} \mathrm{ha}^{-1}$ (326.93 kg ha ${ }^{-1}$ and $205.83 \mathrm{~kg} \mathrm{ha}^{-1}$, respectively) which is at par with the treatment combination of $\mathrm{T}_{6}-\mathrm{N}_{20} \mathrm{P}_{40} \mathrm{~K}_{40}$ and neem cake@0.0 q ha ${ }^{-1}\left(319.60 \mathrm{~kg} \mathrm{ha}^{-1}\right.$ and 
$197.27 \mathrm{~kg} \mathrm{ha}{ }^{-1}$, respectively) and $\mathrm{T}_{7}-$ $\mathrm{N}_{20} \mathrm{P}_{40} \mathrm{~K}_{40}$ and neem cake @ $2.5 \mathrm{q} \mathrm{ha}^{-1}$ (320.65 $\mathrm{kg} \mathrm{ha}{ }^{-1}$ and $201.83 \mathrm{~kg} \mathrm{ha}^{-1}$, respectively) (Table 4). The combined use of neem cake, that in a form of organic manure, and a inorganic fertilizer will increase nutrient use efficiency and reduce environmental stress (Bationo, 2008).

Table.1 Chemical properties of soil

\begin{tabular}{|c|c|c|}
\hline Particulars & Results & Method employed \\
\hline Soil pH (1:2) & 7.6 & Digital pH meter (Jackson, 1958) \\
\hline Soil EC $\left(\mathrm{dSm}^{-1}\right)$ & 0.60 & Digital EC meter (Wilcox, 1950) \\
\hline Organic Carbon (\%) & 0.47 & $\begin{array}{l}\text { Rapid titrations method (Walkley and } \\
\text { Black, 1947) }\end{array}$ \\
\hline Available Nitrogen $\left(\mathrm{kg} \mathrm{ha}^{-1}\right)$ & 235.65 & $\begin{array}{l}\text { Kjeldhal distillation Method (Subbaih and } \\
\text { Asija, 1956) }\end{array}$ \\
\hline Available Phosphorus (kg ha $\left.{ }^{-1}\right)$ & 20.92 & Colorimetric method (Olsen et al., 1954) \\
\hline Available Potassium $\left(\mathrm{kg} \mathrm{ha}^{-1}\right)$ & 126.82 & $\begin{array}{l}\text { Flame photometric method (Toth and Price, } \\
\text { 1949) }\end{array}$ \\
\hline
\end{tabular}

Table.2 Effect of NPK and Neem cake on soil physical properties

\begin{tabular}{|c|c|c|c|}
\hline \multirow[t]{2}{*}{ Treatments } & \multicolumn{3}{|c|}{ Physical properties } \\
\hline & $\begin{array}{l}\text { Bulk Density } \\
\left(\mathrm{Mg} \mathrm{m}^{-3}\right)\end{array}$ & $\begin{array}{l}\text { Particle Density } \\
\left(\mathrm{Mg} \mathrm{m}^{-3}\right)\end{array}$ & $\begin{array}{c}\text { Pore } \\
\text { Space }(\%)\end{array}$ \\
\hline \multicolumn{4}{|c|}{ Fertility levels (NPK) } \\
\hline $\mathbf{L}_{0}-$ Control & 1.11 & 2.31 & 46.64 \\
\hline$L_{1}-N_{10} P_{20} K_{20}$ & 1.08 & 2.50 & 49.67 \\
\hline$L_{2}-N_{20} P_{40} K_{40}$ & 1.06 & 2.61 & 49.01 \\
\hline S.Ed & 0.02 & 0.12 & 1.10 \\
\hline $\mathrm{CD}(\mathrm{P}=0.05)$ & 0.05 & 0.25 & 2.34 \\
\hline \multicolumn{4}{|l|}{ Neem Cake } \\
\hline $\mathbf{N}_{0}-$ Control & 1.10 & 2.42 & 48.32 \\
\hline $\mathrm{N}_{1-} 2.5 \mathrm{q} \mathrm{ha} \mathrm{a}^{-1}$ & 1.09 & 2.48 & 47.99 \\
\hline$N_{2}-5.0 q$ ha $^{-1}$ & 1.08 & 2.51 & 49.01 \\
\hline S.Ed & 0.02 & 0.12 & 1.10 \\
\hline $\mathrm{CD}(\mathrm{P}=0.05)$ & 0.05 & 0.25 & 2.34 \\
\hline
\end{tabular}


Table.3 Effect of NPK and Neem cake on soil chemical properties

\begin{tabular}{|c|c|c|c|c|c|c|}
\hline Treatments & pH & $E C\left(d S m^{-1}\right)$ & $\begin{array}{c}\text { Organic } \\
\text { carbon } \\
(\%)\end{array}$ & $\begin{array}{c}\text { Available } \\
\text { nitrogen } \\
\left(\mathrm{kg} \mathrm{ha}^{-1}\right)\end{array}$ & $\begin{array}{c}\text { Available } \\
\text { Phosphorus } \\
\left.\text { (kg ha }^{-1}\right)\end{array}$ & $\begin{array}{c}\text { Available } \\
\text { Potassium } \\
\left(\mathrm{kg} \mathrm{ha}^{-1}\right)\end{array}$ \\
\hline \multicolumn{7}{|l|}{$\begin{array}{l}\text { Fertility levels } \\
\text { (NPK) }\end{array}$} \\
\hline $\mathbf{L}_{0}-$ Control & 7.12 & 0.19 & 0.58 & 287.70 & 23.20 & 143.45 \\
\hline $\mathbf{L}_{1}-\mathbf{N}_{10} \mathbf{P}_{20} K_{20}$ & 6.98 & 0.22 & 0.70 & 309.41 & 28.22 & 177.14 \\
\hline $\mathbf{L}_{2}-\mathbf{N}_{20} \mathbf{P}_{40} \mathbf{K}_{40}$ & 6.93 & 0.23 & 0.75 & 322.39 & 31.88 & 201.64 \\
\hline S.Ed & 0.04 & 0.003 & 0.01 & 4.13 & 0.31 & 3.61 \\
\hline $\mathrm{CD}(\mathrm{P}=0.05)$ & 0.09 & 0.006 & 0.02 & 8.83 & 0.65 & 7.49 \\
\hline \multicolumn{7}{|l|}{ Neem Cake } \\
\hline $\mathbf{N}_{0}-$ Control & 7.06 & 0.20 & 0.64 & 299.17 & 26.34 & 165.55 \\
\hline $\mathrm{N}_{1}-2.5 \mathrm{q} \mathrm{ha}^{-1}$ & 7.00 & 0.21 & 0.67 & 308.42 & 27.76 & 173.31 \\
\hline$N_{2}-5.0 q h^{-1}$ & 6.98 & 0.22 & 0.71 & 311.91 & 29.19 & 183.37 \\
\hline S.Ed & 0.04 & 0.003 & 0.01 & 4.13 & 0.31 & 3.61 \\
\hline $\mathrm{CD}(\mathrm{P}=0.05)$ & 0.09 & 0.006 & 0.02 & 8.83 & 0.65 & 7.49 \\
\hline
\end{tabular}

Table.4 Interactive effect of NPK and Neem Cake on Organic carbon, available nitrogen, phosphorus and potassium

\begin{tabular}{|c|c|c|c|c|}
\hline Treatments & $\begin{array}{c}\text { Organic } \\
\text { carbon }(\%)\end{array}$ & $\begin{array}{c}\text { Available } \\
\text { nitrogen } \\
\left(\mathrm{kg} \mathrm{ha}^{-1}\right)\end{array}$ & $\begin{array}{c}\text { Available } \\
\text { Phosphoru } \\
\text { S } \\
\left(\mathrm{kg} \mathrm{ha}^{-1}\right)\end{array}$ & $\begin{array}{c}\text { Available } \\
\left.\text { Potassium } \text { (kg ha }^{-1}\right)\end{array}$ \\
\hline $\mathbf{T}_{0}-\mathbf{L}_{0} \mathbf{N}_{0}$ (control) & 0.54 & 274.21 & 21.70 & 130.98 \\
\hline $\begin{array}{l}\mathrm{T}_{1}-\mathrm{L}_{0} \mathrm{~N}_{1} \text { (control + neem cake @ } \\
\left.2.5 \mathrm{q} \mathrm{ha}^{-1}\right)\end{array}$ & 0.58 & 293.40 & 22.90 & 145.95 \\
\hline $\begin{array}{l}\mathrm{T}_{2}-\mathrm{L}_{0} \mathrm{~N}_{2}(\text { control + neem cake @ } \\
\left.5.0 \mathrm{qh}^{-1}\right)\end{array}$ & 0.64 & 295.50 & 25.10 & 153.43 \\
\hline$T_{3}-L_{1} N_{0}\left(N_{10} P_{20} K_{20}+\right.$ control $)$ & 0.67 & 303.71 & 26.94 & 168.40 \\
\hline $\begin{array}{l}T_{4}-L_{1} N_{1}\left(N_{10} P_{20} K_{20}+\text { neem cake @ }\right. \\
\left.2.5 q \text { ha }^{-1}\right)\end{array}$ & 0.69 & 311.22 & 28.81 & 172.14 \\
\hline $\begin{array}{l}T_{5}-L_{1} N_{2}\left(N_{10} P_{20} K_{20}+\text { neem cake @ }\right. \\
\left.5.0 \text { ha }^{-1}\right)\end{array}$ & 0.73 & 313.31 & 28.89 & 190.86 \\
\hline$T_{6}-L_{2} N_{0}\left(N_{20} P_{40} K_{40}+\right.$ control $)$ & 0.73 & 319.60 & 30.38 & 197.27 \\
\hline $\begin{array}{l}T_{7}-L_{2} N_{1}\left(N_{20} P_{40} K_{40}+\text { neem cake @ }\right. \\
\left.2.5 \text { q ha }^{-1}\right)\end{array}$ & 0.75 & 320.65 & 31.58 & 201.83 \\
\hline $\begin{array}{l}T_{8}-L_{2} N_{2}\left(N_{20} P_{40} K_{40}+\text { neem cake @ }\right. \\
\left.5.0 \text { ha }^{-1}\right)\end{array}$ & 0.78 & 326.93 & 33.68 & 205.83 \\
\hline S.Ed & 0.02 & 7.15 & 0.31 & 6.25 \\
\hline $\mathrm{CD}(\mathrm{P}=\mathbf{0 . 0 5})$ & 0.03 & 9.27 & 0.73 & 12.97 \\
\hline
\end{tabular}




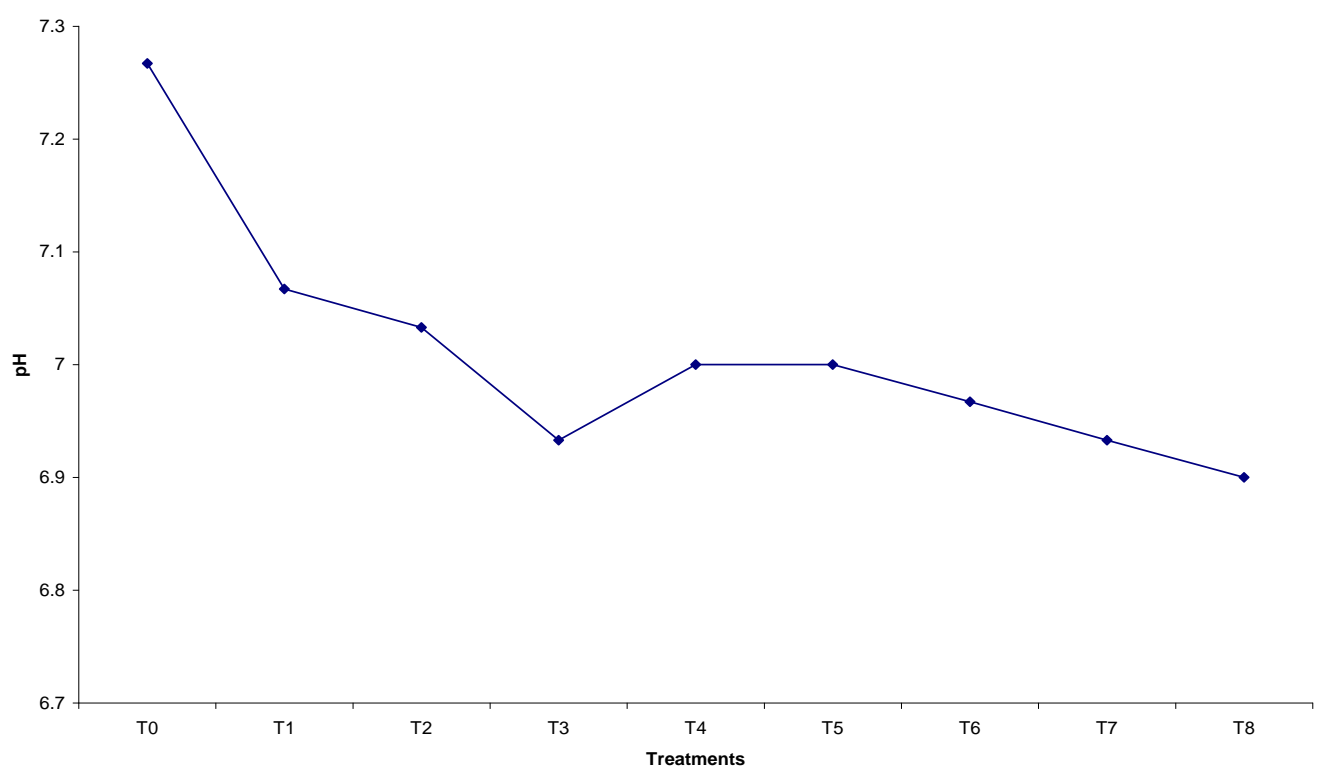

Fig.1 Interaction effect of NPK and Neem cake on soil $\mathrm{pH}$ after crop harvest

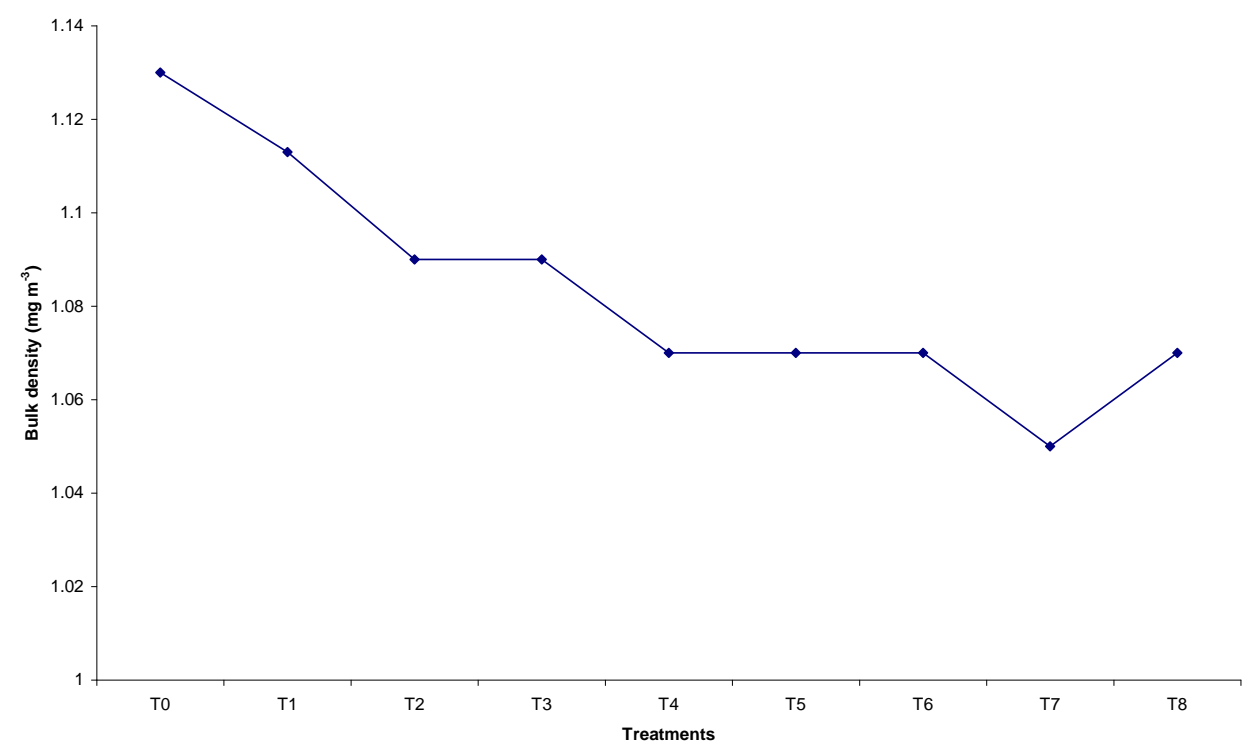

Fig.2 Interaction effect of NPK and Neem cake on Bulk density $\left(\mathrm{Mg} \mathrm{m}^{-3}\right)$ of soil after crop harvest

The results obtained in this experiment indicated that $\mathrm{N}_{20} \mathrm{P}_{40} \mathrm{~K}_{40}$ with neem cake @ $5.0 \mathrm{q} \mathrm{ha}^{-1}$ improves the soil physical and chemical properties of soil than other treatments. So, physical and chemical properties of soil can be achieved by judicious application of NPK and neem cake.

\section{Acknowledgements}

The authors are heartily thankful to Department of Soil Science, Allahabad College of Agriculture, SHUATS, Allahabad (U.P.) for providing field trial facilities and also thankful to the Dean, Allahabad College of Agriculture, Allahabad for providing the facilities for the investigation. 


\section{References}

Agricultural Statistics at a Glance 2018. Directorate of Economics and Statistics. Area, production and yield along with coverage under irrigation, pp- 131 .

Bationo, A. 2008. Integrated soil fertility management options for agricultural intensification in the Sudano-Sahelian zone of West Africa. Academic Science Publishers, Nairobi, Kenya, p. 240.

Brady, A.C. and Weil, R.R. 2002. The Nature and Properties of Soils. 13th Edn. Prentice Hall, New jersey, USA.

Jackson, M.L. 1958. Soil chemical analysis, Second edition Indian Reprint, prentice hall of India, New Delhi. p. 498.

Katyayan, A. 2012. Manures, fertilizers and biofertilizers, Fundamentals of agriculture. Kushal publications and distributors Varanasi, 1: 231-254.

Kherawat, B.S., Agarwal, M.L., Yadav, H.K. and Kumar, S. 2013. Effect of applied potassium and manganese on yield and uptake of nutrients by cluster bean (Cyamopsis tetragonoloba). Journal of Agricultural Physics, 13(1):22-26.

Kumar, J. 2008. Physico-chemical properties of the soil, under the two forest plantation stands around Varanasi (U.P.) India.

Lokanadhan, S., Muthukrishnan, P. and Jeyaraman, S. 2012. Neem products and their agricultural applications, 5:72-76.

Olsen, S.R., Cole, C.V., Watanable, F.S. and
Dean, L.A. 1954. Estimation of available phosphorus in soils by extraction with sodium bicarbonate. Circular, United States Department of Agriculture, p. 932.

Porter, L.K., Follet, R.F. and Halvorson, A.D. 1996. Fertilizer nitrogen recovery in a no-till wheat-sorghum fallow-wheat sequence. Agronomy Journal, 88: 750757.

Subbaih, B.V. and Asija, C.L. 1956. A rapid procedure for the estimation of available nitrogen in soils. Current sciences, 25:256-260.

Takase, M., Sam-Amoah, Owusu, L. K. and Sekyere, J. D. 2011. The Effects of Four Sources of Irrigation Water on Soil Chemical and Physical Properties. Asian Journal of Plant Sciences 10(1): 92-96

Toth, S.J. and Prince, A.L. 1949. Estimation of cation exchange capacity and exchangeable $\mathrm{Ca}, \mathrm{K}$, and $\mathrm{Na}$ content of soil by flame photometer technique. Soil Science, 67:439-445.

Walkley, A. and Black, I.A. 1947. Critical examination of rapid method for determining organic carbon in soils, effect of variance in digestion conditions and of inorganic soil constituents. Soil science, p. 632:251.

Wilcox, L.V. 1950. Electrical conductivity, American Water Works Association, 42:775-776.

\section{How to cite this article:}

Bhanwar Lal Choudhary, Jitendra Singh Bamboriya, Tarence Thomas, Sarita and Shankar Lal Bijarnia. 2020. Effect of NPK and Neem Cake on Physical and Chemical Properties of Soil in Cluster Bean (Cyamopsis tetragonoloba L.) Cv. Pusa Navbahar. Int.J.Curr.Microbiol.App.Sci. 9(04): 1777-1783. doi: https://doi.org/10.20546/ijcmas.2020.904.208 